\title{
A novel protocol for assessing aquatic pollution, based on the feeding inhibition of Daphnia magna
}

\author{
A. Kovács ${ }^{(1)}$, N.-A. Abdel-Hameid ${ }^{(1,2) \star}$, A. Ács ${ }^{(1)}$, Á. Ferincz $^{(1)}$, N. Kováts ${ }^{(1)}$ \\ Received October 18, 2011 \\ Revised January 17, 2012 \\ Accepted January 24, 2012
}

\section{ABSTRACT}

Key-words: Daphnia magna, copper, whole effluent, feeding activity inhibition
In this study, sensitivity of a novel acute bioassay based on the feeding activity of Daphnia magna was assessed, using 2 and $4 \mathrm{~h}$ of exposure. For calibration purposes, results were compared with those of the standard immobility test as described by the ISO 6341:1996 standard. Using potassium dichromate as the reference chemical, after $4 \mathrm{~h}$ of exposure the proposed protocol showed similar sensitivity in comparison with the standard, as the $E C_{50}$ of the immobility test was $1.093 \pm 0.098 \mathrm{mg} \cdot \mathrm{L}^{-1}$, whereas the $E C_{50}$ of the feeding inhibition bioassay was $1.742 \pm 0.133 \mathrm{mg} \cdot \mathrm{L}^{-1}$. In order to test the sensitivity of the bioassay, toxicity of two other contaminants, copper and wastewater, was estimated and the results were compared with those of the standard immobility test. For both cases, the feeding inhibition test showed higher sensitivity, as in the case of copper the $E C_{50 \text { s }}$ were $0.0952 \pm 0.0087$ and $0.0753 \pm 0.0152 \mathrm{mg} \cdot \mathrm{L}^{-1}$, whilst the $E C_{50}$ recorded for the 24-h immobility test was $0.2407 \pm 0.0159 \mathrm{mg} \cdot \mathrm{L}^{-1}$. In the case of the effluent, $E C_{50}$ values after 2 and $4 \mathrm{~h}$ of exposure were $15.698 \pm 2.681$ and $12.557 \pm 2.358$ expressed as \% of the wastewater, respectively, whereas the $E C_{50}$ of the immobility test was calculated to be $36.4688 \pm 5.4887$.

\section{RÉSUMÉ}

Nouveau protocole pour l'évaluation de la pollution aquatique, basé sur l'inhibition de I'alimentation de Daphnia magna

Mots-clés :
Daphnia magna,
cuivre,
effluent total,
inhibition de
l'activité
d'alimentation

Dans cette étude, la sensibilité d'un nouveau test biologique aiguë basé sur l'activité d'alimentation de Daphnia magna a été évaluée, utilisant 2 et $4 \mathrm{~h}$ d'exposition. À des fins d'étalonnage, les résultats ont été comparés à ceux de l'essai standard d'inhibition de la mobilité tel que décrit par la norme ISO 6341:1996 standard. En utilisant le potassium dichromate comme produit chimique de référence, après $4 \mathrm{~h}$ d'exposition, le protocole proposé a montré une sensibilité similaire en comparaison de la norme, alors que la $E C_{50}$ du test d'inhibition de la mobilité était 1,093 \pm $0,098 \mathrm{mg} \cdot \mathrm{L}^{-1}$, la $E C_{50}$ de l'essai biologique d'inhibition d'alimentation a été $1,742 \pm$ $0,133 \mathrm{mg} \cdot \mathrm{L}^{-1}$. Afin de tester la sensibilité du test biologique, la toxicité de deux autres contaminants, du cuivre et des eaux usées, a été estimée et les résultats ont été comparés à ceux du test de l'inhibition de mobilité standard. Pour les deux cas, le test d'inhibition d'alimentation a montré une sensibilité plus élevée. Dans le cas du cuivre, les $E C_{50}$ ont été $0,0952 \pm 0,0087$ et $0,0753 \pm 0,0152 \mathrm{mg} \cdot \mathrm{L}^{-1}$, alors que la

(1) Department of Limnology, University of Pannonia, Egyetem u. 10., P.O.B. 158, 8200, Veszprém, Hungary

(2) Department of Zoology, Faculty of Science, Benha University, Benha, Egypt Pf 13518, Egypt

*Corresponding author: nassr65@gmail.com 
$E C_{50}$ enregistrée pour le test d'inhibition de la mobilité de 24 h était 0,2407 \pm $0,0159 \mathrm{mg} \cdot \mathrm{L}^{-1}$. Dans le cas de l'effluent, les valeurs $E C_{50}$ après 2 et $4 \mathrm{~h}$ d'exposition étaient $15.698 \pm 2.681$ et $12.557 \pm 2.358$ exprimés en \% des eaux usées, respectivement, alors que la valeur calculée $E C_{50}$ du test d'inhibition de la mobilité était $36.4688 \pm 5.4887$.

\section{INTRODUCTION}

D. magna is one of the most widely used test organisms in ecotoxicology (Persoone et al., 2009; Jeon et al., 2010). The ISO 6341:1996 standard uses Daphnia magna Straus in an acute toxicity test, where the exposure is 24 and/or $48 \mathrm{~h}$ with an endpoint of inhibition of motility, practically mortality. To minimise the differences and uncertainties emerging from the application of various genotypes and to avoid the expensive maintenance of stock cultures, toxkits have been developed such as the Daphtoxkit $\mathrm{F}^{\mathrm{TM}}$ which contains dormant eggs, ephippia, as a source of neonates whenever they are required (Persoone, 1996).

However, while mortality is an ultimate and non-specific endpoint, its relevance to forecasting ecological threat can be questioned. More attempts have been made to specify other ecological effects which can be used as potential test endpoints. Baylor used Daphnia heart beat rate tests (Baylor, 1942) as early as 1942, which is still considered an applicable endpoint (Villegas-Navarro et al., 2003). Some authors recorded morphological abnormalities (e.g. Leoni et al., 2008). Wu et al. (2008) suggested the phototaxic index (response to the light) of $D$. carinata as an appropriate test endpoint for toxicity testing of environmental contaminants. Recording movement patterns such as average speed, turns and circling movements is relatively widely used (e.g. Untersteiner et al., 2003; Jeon et al., 2008). The IQ Toxicity Test ${ }^{\mathrm{TM}}$ kit developed by Aqua Survey, Inc. is based on fluorescent tagging of metabolic processes of the test organisms. In this assay daphnids are fed a fluorescent sugar reagent. In the presence of toxins, the metabolism of Daphnia magna is reduced, blocking their normally visible light emittance. Some authors suggest a close relation between decreased grazing activity and damage of the digestive tract of daphnids caused by some toxicants (Nogueira et al., 2006; Soares et al., 2009). Life-history traits such as somatic (individual) growth (Burks et al., 2000), time to first reproduction, development of parthenogenetic eggs (Sobral et al., 2001; Khangarot and Das, 2009) and number of newborns (Lürling and van der Grinten, 2000) can also be studied. Lürling (2003) used population growth as the measure of toxic effect. These assays provide an alternative approach to studying the ecological response of daphnids other than mortality, yet some of them are difficult to quantify. An assay based on feeding activity of $D$. magna was developed by our team. The test gives quantifiable results and can be applied in routine testing.

Our aim was to assess the sensitivity of this new method, in comparison with the standard immobility test using potassium dichromate as the reference toxicant. Reference values are presented in the ISO 6341 standard, where the immobility test can be considered valid if the 24-h $E C_{50}$ falls in the $0.6-2.1 \mathrm{mg} \cdot \mathrm{L}^{-1}$ range. In order to test the sensitivity of the novel assay, toxicity of two other contaminants, copper sulphate and wastewater, was estimated and results were compared with those of the standard immobility test.

Copper is a predominant pollutant in aquatic habitats as copper-based compounds have been used as herbicides, algicides and molluscicides. Its environmental levels range from 0.00004-0.294 mg. $\mathrm{L}^{-1}$ (An and Kampbell, 2003), reaching $20 \mathrm{mg} \cdot \mathrm{L}^{-1}$ in critical situations (Goodyear and McNeill, 1999). Copper is one of the metals included in the EU Water Framework Directive (WFD) list of priority substances (Banas et al., 2010). The effects of copper have been demonstrated with studies on the inhibition of motility of daphnids (De Schamphelaere et al., 2002; Jonczyk and Gilron, 2005; Pernet-Coudrier et al., 2008; Kungolos et al., 2009; Park et al., 2009; Jeon et al., 2010).

Municipal wastewater is one of the major sources of pollutants introduced into the aquatic environment (Gros et al., 2010). The discharge of municipal wastewater effluents can have 
negative effects on the community and population structure of the receiving water body. The whole-effluent toxicity of municipal wastewater treatment plants can be greatly variable because the effluents are a mixture of various chemicals (Mitteregger et al., 2007). To assess whole-effluent toxicity, the Daphnia immobility test according to ISO 6341:1996 is generally prescribed by national regulations such as, for example, the 27/2005 Decree of the (Hungarian) Minister for Environmental Affairs and Water Management on the control of discharging used and wastewaters.

\section{MATERIALS AND METHODS}

Potassium dichromate (Renal, Rt., Hungary) stock solution (1.982 $\mathrm{mg} \cdot \mathrm{L}^{-1}$ ) was used to prepare 5 serial dilutions $\left(0.124,0.248,0.495,0.991\right.$ and $\left.1.982 \mathrm{mg} \cdot \mathrm{L}^{-1}\right)$. Copper sulphate $\left(\mathrm{CuSO}_{4}\right.$; anhydrous, Renal, Rt., Hungary) was tested at five concentrations (0.024, 0.049, $0.059,0.079$ and $0.099 \mathrm{mg} \cdot \mathrm{L}^{-1}$, values are presented as $\mathrm{Cu}$ ). Untreated municipal wastewater was collected from a municipal wastewater treatment plant, and stored at $+2{ }^{\circ} \mathrm{C}$ until testing the day following the collection. Five serial dilutions (v:v), using synthetic freshwater $(6.25$, $12.5,25,50$ and 100\%) were used. The synthetic freshwater (supplied by Microbiotest Inc., Belgium) was used for preparing serial dilutions of the tested pollutants and for the control.

For both the immobility test and the feeding inhibition test, Daphtoxkit $\mathrm{F}^{\mathrm{TM}}$ kits (Microbiotest Inc., Belgium) were used as the source of the test organisms. Neonates were hatched from ephippia after 3 days of incubation at $20{ }^{\circ} \mathrm{C}$ in synthetic freshwater, under continuous illumination (light source 10000 lux). The immobility test was carried out according to the protocol described by the ISO 6341:1996 standard. Briefly, daphnids were exposed in the sample at $20 \pm 1{ }^{\circ} \mathrm{C}$ in the dark. The number of immobile organisms was recorded after $24 \mathrm{~h}$ of exposure. Four replicates were used.

The $D$. magna feeding inhibition toxicity assays were carried out as described by Ács et al. (2009). Neonates were exposed to five serial dilutions in addition to the control and incubated at $20^{\circ} \mathrm{C}$ in darkness for periods of $2 \mathrm{~h}$ and $4 \mathrm{~h}$. Immediately after incubation, $0.2 \mathrm{ml}$ of red polystyrene microsphere suspension with a particle size of $5 \mu \mathrm{m}$ (MicroBiotest Inc., Ghent, Belgium) were added to each cell. Daphnids were allowed to feed for $30 \mathrm{~min}$ at $20{ }^{\circ} \mathrm{C}$ in darkness. After incubation, a fixative was added, and the number of daphnids with red microspheres in their digestive tracts was recorded using a stereomicroscope. Again, four replicates were used. The mean percentage of feeding inhibition $(F I)$ of particle uptake for each replicate was calculated using the following formula: $F I=100(A-B) / A$, where $A$ is the mean percentage particle uptake in the control, and $B$ is the mean percentage particle uptake in the test solution.

The $E C_{50}$ values were calculated using probit analysis according to Finney (1971). All data $\left(E C_{50}\right)$ are expressed as mean $\pm \mathrm{SE}$. For statistical analysis, Welch's ANOVA was used, to discover significant differences between pairwise groups.

\section{RESULTS}

The data presented in Figure 1 show the potassium dichromate $E C_{50 \mathrm{~s}}$ for both the immobility and feeding inhibition tests. For the standard immobility test, the 24-h $E C_{50}$ was $1.093 \pm$ $0.098 \mathrm{mg} \cdot \mathrm{L}^{-1}$. For the feeding inhibition test, the $2-\mathrm{h} E C_{50}$ was $4.190 \pm 0.491$, which falls outside the range of validity as defined by the ISO 6341 standard. In the case of $4 \mathrm{~h}$ of exposure, the $E C_{50}(1.742 \pm 0.133)$ fell within the same range as the standard immobility test. Toxicity of copper determined by the feeding inhibition test was as follows: the 2-h $E C_{50}$ was $0.0952 \pm 0.0087 \mathrm{mg} \cdot \mathrm{L}^{-1}$ and the $4-\mathrm{h} E C_{50}$ was $0.0753 \pm 0.0152 \mathrm{mg} \cdot \mathrm{L}^{-1}$ (Figure 2). In comparison with the $E C_{50}$ of the standard immobility test, $0.2407 \pm 0.0159 \mathrm{mg} \cdot \mathrm{L}^{-1}$, these results show higher sensitivity. The $E C_{50 \text { s }}$ of the 2- or 4-h feeding tests may reflect actual 
- Potassium dichromate

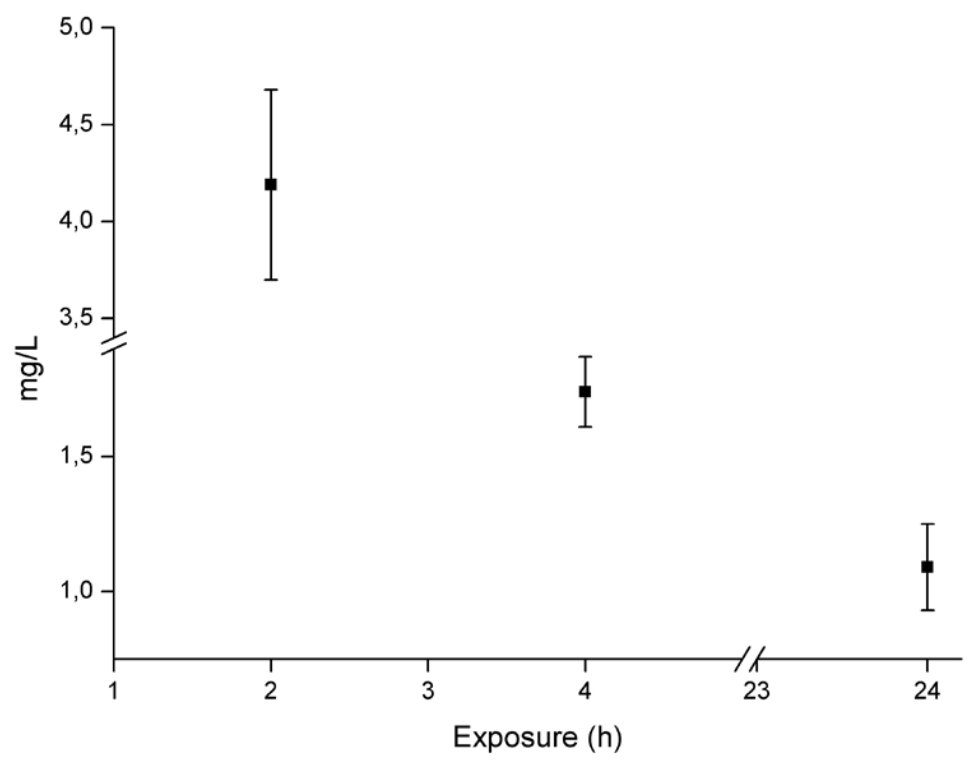

Figure 1

Acute toxicity, $E C_{50}$ of potassium dichromate $\left(\mathrm{mg} \cdot \mathrm{L}^{-1}\right)$ to Daphnia magna, using novel feeding inhibition assay test compared with normal mortality test $\left(24 h \mathrm{EC}_{50}\right)$.

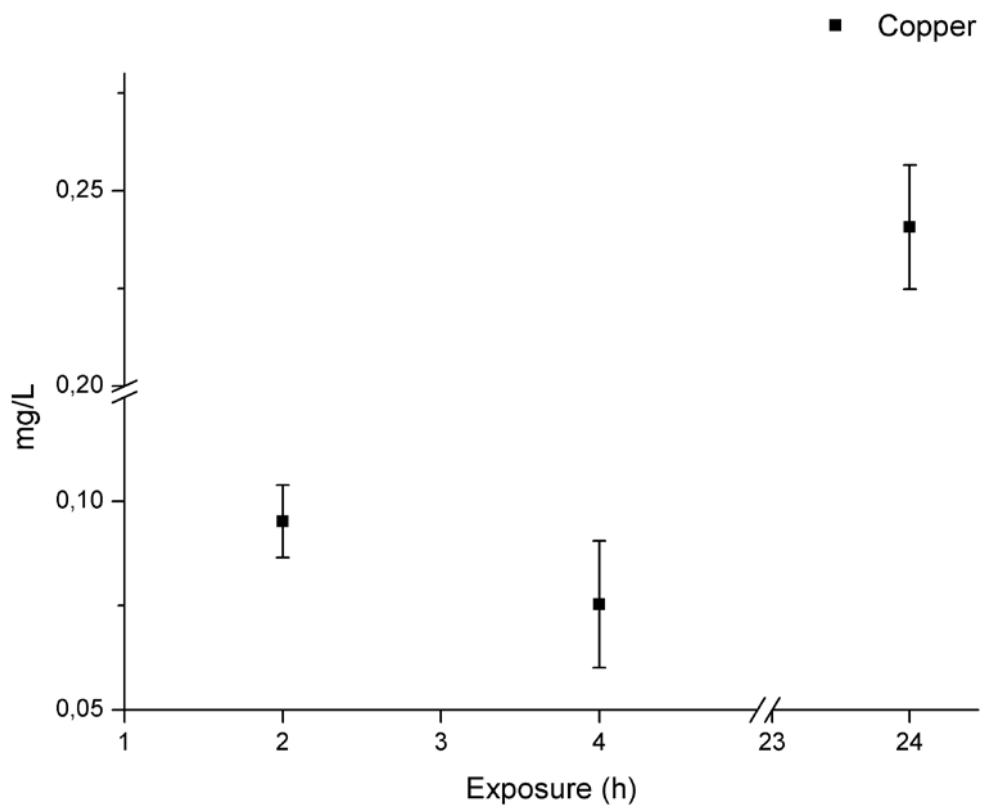

Figure 2

Acute toxicity, $E C_{50}$ of copper $\left(\mathrm{mg} \cdot \mathrm{L}^{-1}\right)$ to Daphnia magna, using novel feeding inhibition assay test compared with normal mortality test (24 $\left.h \mathrm{EC}_{50}\right)$.

environmental concentrations, as Neal et al. (1996) reported copper levels of $0.034 \mathrm{mg} \cdot \mathrm{L}^{-1}$ in the Rhine River, whilst the environmental quality standard $(E Q S)$ is $0.006-0.01 \mathrm{mg} \cdot \mathrm{L}^{-1}$.

For the whole-effluent sample, $E C_{50}$ values of the feeding inhibition test after 2 and $4 \mathrm{~h}$ of exposure were $15.698 \pm 2.681$ and $12.557 \pm 2.358$ expressed as $\%$ of the wastewater, respectively (Figure 3). The $E C_{50}$ of the immobility test was $36.4688 \pm 5.4887$, also expressed as $\%$ concentration of the effluent. 


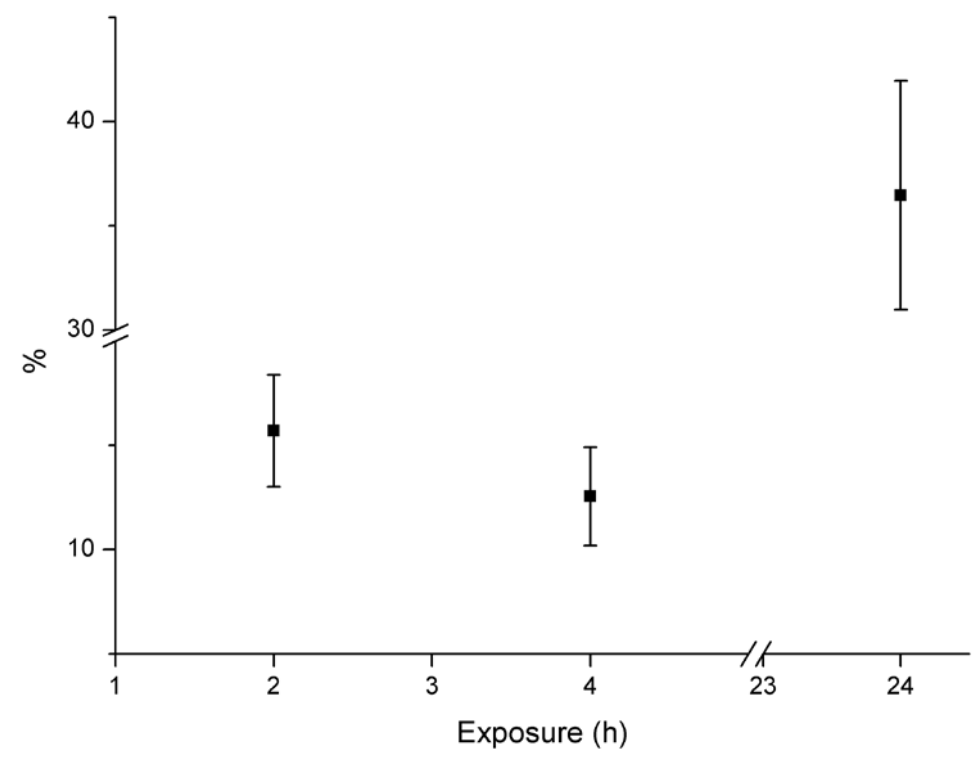

Figure 3

Acute toxicity, $E_{50}$ of wastewater (\% effluent) to Daphnia magna, using novel feeding inhibition assay test compared with normal mortality test $\left(24 \mathrm{~h} \mathrm{EC}_{50}\right)$.

For statistical analysis, Welch's ANOVA was used. For $\mathrm{K}_{2} \mathrm{Cr}_{2} \mathrm{O}_{7}$ and for copper, the $E C_{50}$ was significantly affected by exposure time (Fdf1df2 $=95.531, P<0.0001$; Fdf1df2 $=149.433$, $P<0.0001$, respectively), and all conditions differed significantly from each other (XX posthoc test, alpha $=0.05)$. For the wastewater effluent, the effect of exposure time was also significant $(F d f 1, d f 2=42.244, P<0.0001)$, yet the difference was significant only between $E C_{50}-24 \mathrm{~h}$ on the one hand, and $2 \mathrm{~h}$ and $4 \mathrm{~h}$, on the other hand.

\section{DISCUSSION}

Feeding behaviour of zooplankton could be considered as an important endpoint in ecotoxicological studies (Kiss et al., 2003; Palanivelu et al., 2005). The inhibition of feeding has been applied by several authors to assess the possible ecotoxicological effects of different contaminants, such as metals (Flickinger et al., 1982; Ferrando and Andreu, 1993) and pesticides (Fernandez-Cassalderrey et al., 1994). Hartgers et al. (1999) and Lürling et al. (2011) found that the clearance rate of Daphnia magna using artificial beads is a more sensitive endpoint than an acute lethal test. Alterations in the feeding and digestive behaviour of daphnids as endpoints were compared by De Coen and Janssen (1998) and De Coen et al. (1998), where ingestion rate was assessed using fluorescent microbeads and measuring fluorescence. In these studies, a clear inhibition of the ingestion activity was experienced, while the digestive enzyme activity proved to be less affected.

From an ecological point of view, feeding inhibition can be considered as a relevant endpoint. Also, considering reliability, the proposed protocol shows equal or higher sensitivity than the standard immobility test. In the case of potassium dichromate, the 2-h $E C_{50}$ showed lower sensitivity than either the 4-h or 24-h mortality $E C_{50 \text { s. }}$. However, after longer ( $\left.4 \mathrm{~h}\right)$ exposure, the feeding inhibition test proved to have similar sensitivity in comparison with the standard immobility test and also gave valid results according to the ISO 6341 standard. It is important to note that, in the case of the other chemicals tested, the novel protocol showed higher sensitivity than the standard immobility test: 2- and 4-h copper as well as 2- and 4-h whole effluent. 
In conclusion, this novel acute bioassay provides more accurate and earlier responses. This is a necessary requirement for toxicity assessment in aquatic habitats and provides more protection to aquatic organisms. In addition, using a sublethal endpoint, feeding inhibition, is regarded as ecologically more relevant. Using shorter exposure, it gives earlier information on the toxicity of the sample. Finally, the protocol fulfils quality assurance components such as repeatability which means it can be applied in routine testing.

\section{REFERENCES}

Ács A., Kováts N. and Refaey M., 2009. Novel Daphnia test for detecting chemical pollution. In: Simeonoy L.I. and Hassanien M.A. (eds.), Exposure and risk assessment of chemical pollution Contemporary Methodology, Springer, 439-444.

An Y. and Kampbell D.H., 2003. Total, dissolved, and bioavailable metals at Lake Texoma marinas. Environ. Pollut., 122, 253-259.

Banas D., Marin B., Skraber S., Chopin E.I. and Zanella A., 2010. Copper mobilization affected by weather conditions in a storm water detention system receiving runoff waters from vineyard soils (Champagne, France). Environ. Pollut., 158, 476-482.

Baylor E.R., 1942. Cardiac pharmacology of the cladoceran, Daphnia. Biol. Bull., 83, 145-301.

Burks R.L., Jeppesen E., David M. and Lodge D.M., 2000. Macrophyte and fish chemicals suppress Daphnia growth and alter life-history traits. Oikos, 88, 139-147.

De Coen W.M. and Janssen C.R., 1998. The use of biomarkers in Daphnia magna toxicity testing. I. The digestive physiology of daphnids exposed to toxic stress. Hydrobiologia, 367, 199-209.

De Coen W.M., Vangheluwe M.L. and Janssen C.R., 1998. The use of biomarkers in Daphnia magna toxicity testing. III. Rapid toxicity testing of pure chemicals and sediment pore waters using ingestion and digestive enzyme activity. Chemosphere, 37, 2677-2694.

De Schamphelaere K.A.C., Heijerick D.G. and Janssen C.R., 2002. Refinement and field validation of a biotic ligand model predicting acute copper toxicity to Daphnia magna. Comp. Biochem. Physiol., C, 133, 243-258.

Fernandez-Cassalderrey A., Ferrando M.D. and Andreu-Moliner E., 1994. Effects of sublethal concentrations of pesticides on the feeding behaviour of Daphnia magna. Ecotoxicol. Environ. Saf., 27, 82-89.

Ferrando M.D. and Andreu E., 1993. Feeding behavior as an index of copper stress in Daphnia magna and Brachionus calyciflorus. Comp. Biochem. Physiol., C, 106, 327-331.

Finney D.J., 1971. Probit analysis, 3rd edition, Cambridge, UK.

Flickinger A., Bruins R., Winner R. and Skillings J., 1982. Filtration and phototactic behaviour as indices of chronic copper stress in Daphnia magna Straus. Arch. Environ. Contam. Toxicol., 11, 457-463.

Goodyear K.I. and McNeill S., 1999. Bioaccumulation of heavy metals by aquatic macro-invertebrates of different feeding guilds: a review. Sci. Total Environ., 229, 1-19.

Gros M., Petrović M., Ginebreda A. and Barceló D., 2010. Removal of pharmaceuticals during wastewater treatment and environmental risk assessment using hazard indexes. Environ. Int., 36, 15-26.

Hartgers E.M., Heugens E.H. and Deneer J.W., 1999. Effect of Lindane on the clearance rate of Daphnia magna. Arch. Environ. Contam. Toxicol., 36, 399-404.

ISO, 6341, 1996. Water Quality - Determination of the inhibition of the mobility of Daphnia magna Straus (Cladocera, Crustacea) - Acute toxicity test.

Jeon J., Kim J.H., Lee B.C. and Kim S.D., 2008. Development of a new biomonitoring method to detect the abnormal activity of Daphnia magna using automated Grid Counter device. Sci. Total Environ., 389, 545-389.

Jeon J., Ra J.S., Lee S.H., Lee M.J., Yu S.H. and Kim S.D., 2010. Role of food and clay particles in toxicity of copper and diazinon using Daphnia magna. Ecotoxicol. Environ. Saf., 73, 400-406.

Jonczyk E. and Gilron G., 2005. Acute and chronic toxicity testing with Daphnia sp. In: Blaise C. and Férard J.-F. (eds.), Small-scale Toxicity Testing for Freshwater Environments, Kluwer Academic/Plenum Publishers, 337-394.

Khangarot B.S. and Das S., 2009. Toxicity of mercury on in vitro development of parthenogenetic eggs of a freshwater cladoceran Daphnia carinata. J. Hazard. Mater., 161, 68-73.

Kiss I., Kováts N. and Szalay T., 2003. Evaluation of some alternative guidelines for risk assessment of various habitats. Toxicol. Lett., 140-141, 411-417. 
Kungolos A., Emmanouil C., Tsiridis V. and Tsiropoulos N., 2009. Evaluation of toxic and interactive toxic effects of three agrochemicals and copper using a battery of microbiotests. Sci. Total Environ., 407, 4610-4615.

Leoni B., Bettinetti R. and Galassi S., 2008. Sub-lethal effects of acetone on Daphnia magna. Ecotoxicology, 17, 199-205.

Lürling M., 2003. Effects of microcystin-free and Microcystin containing strains of the cyanobacterium Microcystis aeruginosa on growth of the grazer Daphnia magna. Environ. Toxicol., 18, 202-210.

Lürling M. and van der Grinten E., 2000. Life-history characteristics of Daphnia exposed to dissolved microcystin-LR and to the cyanobacterium Microcystis aeruginosa with and without microcystins. Environ. Toxicol. Chem., 22, 1281-1287.

Lürling M., de Lange H.J. and Peeters E.T.H.M., 2011. Effects of an anionic surfactant (FFD-6) on the energy and information flow between a primary producer (Scenedesmus obliquus) and a consumer (Daphnia magna). Ecotoxicology, 20, 1881-1889.

Mitteregger H.M.J., Silva J., Arenzon A., Portela C.S., Ferreira I.C.F. and Henriques J.A.P., 2007. Evaluation of genotoxicity and toxicity of water and sediment samples from a Brazilian stream influenced by tannery industries. Chemosphere, 67, 1211-1217.

Neal C., Smith C.J., Jeffery H.A., Jarvie H.P. and Robson A.J., 1996. Trace element concentrations in the major rivers entering the Humber estuary, NE England. J. Hydrol., 182, 37-64.

Nogueira I.C.G., Lobo-da-Cunha A. and Vasconcelos V.M., 2006. Effects of Cylindrospermopsis raciborskii and Aphanizomenon ovalisporum (cyanobacteria) ingestion on Daphnia magna midgut and associated diverticula epithelium. Aquat. Toxicol., 80, 194-203.

Palanivelu V., Vijayavel K., Ezhilarasibalasubramanian S. and Balasubramanian M.P., 2005. Impact of fertilizer (urea) on oxygen consumption and feeding energetics in the fresh water Oreochromis mossambicus. Environ. Toxicol. Pharmacol., 19, 351-355.

Park E.J., Jo H.J. and Jung J., 2009. Combined effects of pH, hardness and dissolved organic carbon on acute metal toxicity to Daphnia magna. J. Ind. Eng. Chem., 15, 82-85.

Pernet-Coudrier B., Clouzot L., Varrault G., Tusseau-vuillemin M., Verger A. and Mouchel J., 2008. Dissolved organic matter from treated effluent of a major wastewater treatment plant: characterization and influence on copper toxicity. Chemosphere, 73, 593-599.

Persoone G., 1996. Report for the Workshop on the Joint Flemish-Czech Programme on Toxkit Microbiotests, Ghent.

Persoone G., Baudo R., Cotman M., Blaise C., Thompson K.C.I., Moreira-Santos M., Vollat B., Törökne A. and Han T., 2009. Review on the acute Daphnia magna toxicity test - Evaluation of the sensitivity and the precision of assays performed with organisms from laboratory cultures or hatched from dormant eggs. Knowl. Managt. Aquatic Ecosyst., 393, 1-29.

Soares M.C.S., Lürling M., Panosso R. and Huszar V., 2009. Effects of the cyanobacterium Cylindrospermopsis raciborskii on feeding and life-history characteristics of the grazer Daphnia magna. Ecotoxicol. Environ. Saf., 72, 1183-1189.

Sobral O., Chastinet C., Nogueira A., Soares A.M.V.M., Gonialves F. and Ribeiro R., 2001. In vitro development of parthenogenetic eggs: a fast ecotoxicity test with Daphnia magna? Ecotoxicol. Environ. Saf., 50, 174-179.

Untersteiner H., Kahapkam J. and Kaiser H., 2003. Behavioural response of the cladoceran Daphnia magna Straus to sublethal copper stress - validation by image analysis. Aquat. Toxicol., 4, 435-442.

Villegas-Navarro A., Rosas L.E. and Reyes J.L., 2003. The heart of Daphnia magna: effects of four cardioactive drugs. Comp. Biochem. Physiol., C, 136, 127-134.

Wu Y., Lin C. and Yuan L., 2008. Phototaxis index of Daphnia carinata as an indicator of joint toxicity of copper, cadmium, zinc, nitrogen and phosphorus in aqueous solutions. Ecological Indicators, 8, 69-74. 